\title{
Oxidative Stress and Inflammation Caused by Cisplatin Ototoxicity
}

\author{
Vickram Ramkumar ${ }^{1}$, Debashree Mukherjea ${ }^{2}$, Asmita Dhukhwa ${ }^{1}$ and Leonard P. Rybak ${ }^{2, *(D)}$ \\ 1 Department of Pharmacology, School of Medicine, Southern Illinois University, 801 N. Rutledge Street, \\ Springfield, IL 62702, USA; vramkumar@siumed.edu (V.R.); adhukhwa59@siumed.edu (A.D.) \\ 2 Department of Otolaryngology, School of Medicine, Southern Illinois University, 801 N. Rutledge Street, \\ Springfield, IL 62702, USA; dmukherjea@siumed.edu \\ * Correspondence: lrybak@siumed.edu; Fax: +1-217-545-6544
}

Citation: Ramkumar, V.; Mukherjea,

D.; Dhukhwa, A.; Rybak, L.P.

Oxidative Stress and Inflammation

Caused by Cisplatin Ototoxicity.

Antioxidants 2021, 10, 1919. https://

doi.org/10.3390/antiox10121919

Academic Editor: Stanley Omaye

Received: 30 September 2021

Accepted: 28 October 2021

Published: 29 November 2021

Publisher's Note: MDPI stays neutral with regard to jurisdictional claims in published maps and institutional affiliations.

Copyright: (c) 2021 by the authors. Licensee MDPI, Basel, Switzerland. This article is an open access article distributed under the terms and conditions of the Creative Commons Attribution (CC BY) license (https:// creativecommons.org/licenses/by/ $4.0 /)$.

\begin{abstract}
Hearing loss is a significant health problem that can result from a variety of exogenous insults that generate oxidative stress and inflammation. This can produce cellular damage and impairment of hearing. Radiation damage, ageing, damage produced by cochlear implantation, acoustic trauma and ototoxic drug exposure can all generate reactive oxygen species in the inner ear with loss of sensory cells and hearing loss. Cisplatin ototoxicity is one of the major causes of hearing loss in children and adults. This review will address cisplatin ototoxicity. It includes discussion of the mechanisms associated with cisplatin-induced hearing loss including uptake pathways for cisplatin entry, oxidative stress due to overpowering antioxidant defense mechanisms, and the recently described toxic pathways that are activated by cisplatin, including necroptosis and ferroptosis. The cochlea contains G-protein coupled receptors that can be activated to provide protection. These include adenosine A1 receptors, cannabinoid 2 receptors (CB2) and the Sphingosine 1-Phosphate Receptor 2 (S1PR2). A variety of heat shock proteins (HSPs) can be up-regulated in the cochlea. The use of exosomes offers a novel method of delivery of HSPs to provide protection. A reversible MET channel blocker that can be administered orally may block cisplatin uptake into the cochlear cells. Several protective agents in preclinical studies have been shown to not interfere with cisplatin efficacy. Statins have shown efficacy in reducing cisplatin ototoxicity without compromising patient response to treatment. Additional clinical trials could provide exciting findings in the prevention of cisplatin ototoxicity.
\end{abstract}

Keywords: oxidative stress; cisplatin; inflammation; heat shock proteins; G-protein coupled receptors

\section{Introduction}

The cochlea can be damaged by a variety of insults that can result in acquired sensorineural hearing loss. Hearing loss can result from ototoxic drugs, noise trauma, and injury from cochlear implant insertion, ageing and radiation. A common theme demonstrated by these harmful entities is the production of oxidative stress by free radical generation leading to inflammation and loss of sensory cells and reduction in hearing acuity. This review will address cisplatin ototoxicity. It includes an up to date presentation of the mechanisms associated with cisplatin-induced hearing loss, current treatments to ameliorate cisplatin ototoxicity and novel and exciting future treatments that are being explored.

\section{Cisplatin Ototoxicity}

Cisplatin is widely used as a chemotherapeutic agent to treat solid malignant tumors in adults and children [1]. Unfortunately, permanent sensorineural hearing loss is a frequent complication of cisplatin therapy. The higher frequencies are affected initially, but subsequently hearing loss in the middle frequency range can appear when higher doses are administered. Children are more likely than adults to develop delayed ototoxicity from cisplatin [2]. Long-term retention of platinum in the cochlea after cisplatin chemotherapy 
has been demonstrated in pediatric patients [3]. Young children are more susceptible to cisplatin induced hearing loss. Hearing loss from cisplatin develops early during chemotherapy and its cumulative incidence is increased with total cumulative doses of cisplatin and the administration of other ototoxic drugs [4].

Animal models for cisplatin ototoxicity reveal that outer hair cells (OHCs) of the first row of basal turn of the cochlea are the targets for initial damage $[3,5,6]$. Injury extends to additional rows of $\mathrm{OHCs}$ of the basal turn, and then apically with additional dosing [5]. Progressive damage to OHCs include parietal membrane dilation, cuticular plate softening, vacuole formation and accumulation of lysosomes in the apical portion of the cells. Stereocilia fusion can be seen on OHCs and inner hair cells (IHCs) [6]. Platinum preferentially accumulates to the highest concentration in the stria vascularis [3] leading to strial damage, particularly with high dose cisplatin [7].

\section{Mechanisms of Ototoxicity}

The molecular mechanisms by which cisplatin causes cochlear damage and hearing loss are still being studied. Cisplatin needs to enter cells in the cochlea in order to cause cell death. Cisplatin may enter cells by passive diffusion and facilitated transport [8,9]. Cisplatin may also gain access to target cells in the cochlea by using transporters. These include copper transporter 1 (CTR1) [10] and/or organic cation transporters (OCTs), such as OCT 2 [11]. Upon entry into the cells cisplatin may be hydrolyzed by water to generate aqua-cisplatin complexes [12]. These complexes are highly toxic and can damage DNA. This can upregulate ataxia telangiectasia mutated (ATM). ATM can activate the tumor suppressor molecule p53 [13]; this increases the expression of the pro-apoptotic protein, Bcl-associated X (Bax). Bax increases mitochondrial membrane permeability leading to cytochrome c release from mitochondria through activation of caspase 3 [14].

Mechanoelectrical transduction (MET) channels may provide a route of entry for cisplatin into hair cells. Thus, partial or reversible blockade of MET channels may reduce cisplatin ototoxicity. Cisplatin has been found to block MET channels in chick cochlear hair cells in a dose and voltage dependent manner [15]. Iontophoresis of cisplatin into the scala media of guinea pigs resulted in hearing loss by blocking OHC MET channels [16]. Chemical inhibition of MET channels with quinine or EGTA blocked cisplatin uptake and prevented hair cell death in zebrafish [17]. A reversible, high-affinity permeant blocker of the MET channel, ORC-13661, protected neonatal mouse OHCs from cisplatin damage [18]. This finding suggests that less cisplatin was able to enter these OHCs in the presence of MET channel blockade, and thus they were protected from damage. Mice expressing fluorescently labeled transmembrane channel-like protein isoform (TMCs), which are associated with the MET channels exhibit a three-fold increase in the number of TMC1 molecules in the tip of each stereocilium from the apex to the base of the cochlea [19]. These findings could partially explain the greater sensitivity of the base of the cochlea to cisplatin damage resulting in larger threshold shifts at higher frequencies. Potential mechanistic targets underlying cisplatin ototoxicity are presented in Figure 1. 


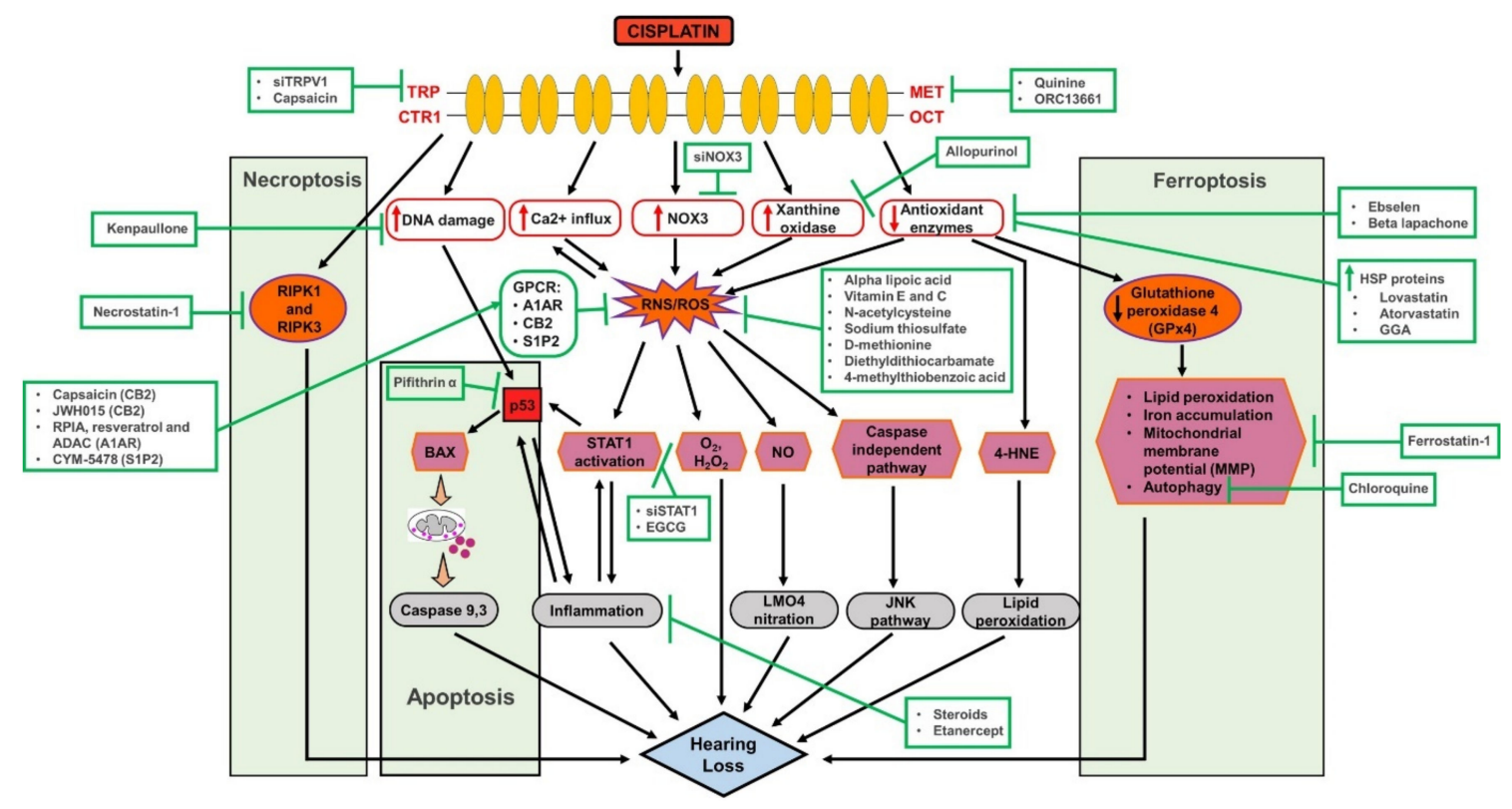

Figure 1. Comprehensive figure of cisplatin ototoxicity and potential targets for otoprotection. Cisplatin entry through several membrane sites including MET (mechanoelectrical transduction), TRP (transient receptor potential) and OCT (organic cation transporters) channels. Several mechanisms of cisplatin ototoxicity are listed, namely the generation of ROS via NOX3, leading to the activation of lipid peroxidation, DNA damage, inflammation and cell death pathways. Several potential targets for otoprotection include inhibition of drug entry (via MET channels), scavenging of ROS (using antioxidants), inhibition of inflammation (using anti-inflammatory drugs) and inhibition of apoptosis (using p53 inhibitors).

\section{Oxidative Stress}

The cochlea has a high rate of metabolism. It requires an active antioxidant defense system in order to manage reactive oxygen species (ROS) generation from normal metabolism to function properly to maintain healthy hearing. This defense mechanism can be overwhelmed when the cochlea is subjected to extreme oxidative stress from noise or ototoxic drugs. Cisplatin ototoxicity is strongly associated with increased oxidative stress in the cochlea $[20,21]$. A key target of cisplatin in the cochlea is the NOX3 isoform of NADPH oxidase [22]. This enzyme is uniquely expressed in the cochlea. Rats treated with trans-tympanic siRNA for NOX3 had reduced ototoxicity from cisplatin [23]. Furthermore, mice treated with cisplatin exhibited increased expression of NOX3 in (OHCs) and supporting cells (SCs) and significant high-frequency hearing loss with auditory brainstem response (ABR) testing. However, NOX3-knockout mice had significantly smaller ABR threshold shifts and fewer OHC loss in all segments of the basal turn of the cochlea. NOX3 expression was found to be increased following cisplatin exposure, aging and noise trauma. The greatest increase of NOX3 expression was found in cisplatin treated mice. Nox3 upregulation, particularly in the basal turn SCs and OHCs, appears to be directly involved in the development of sensorineural hearing loss (SNHL) [24]. Xanthine oxidase is another enzyme that could be a source of ROS generation in the cochlea [25]. Allopurinol is an inhibitor of this enzyme that has been shown to reduce cisplatin ototoxicity when administered in combination with ebselen, a glutathione peroxidase mimic [25].

Cisplatin can also activate nitric oxide synthases in the cochlea [26,27], thus increasing the level of nitric oxide (NO) in the cochlea. NO can react with proteins in the cochlea, resulting in their nitration and loss of function. $\mathrm{NO}$ can also react with $\mathrm{O}_{2}$ - produced by cisplatin upregulation of NOX3 to generate the highly reactive peroxynitrite free radical (ONOO-). Cisplatin induced nitrative stress in the cochlea leads to the nitration of LIM domain only 4 (LMO4), a transcriptional regulator, and decreases its cochlear expression levels. $\mathrm{LMO} 4$ is a transcriptional regulator that controls the choice between cell survival and cell death. Nitration of LMO4 appears to be related to cisplatin-induced ototoxicity [28]. Furthermore, LMO4 knockout animals are more susceptible to cisplatin induced hearing 
loss and apoptosis of cochlea cells [29]. Thus, both ROS and RNS can react with and damage proteins, lipids and DNA within the cell to inhibit their normal function leading to cellular damage and loss of hearing (see Figure 1).

Cisplatin ototoxicity has recently been associated with ferroptosis [30,31]. Ferroptosis is a type of cell death that is not apoptotic. It can be activated by various small molecules, such as cisplatin, or it can be induced by inhibition of the biosynthesis of glutathione or inhibition of glutathione peroxidase 4 (GPx4). It involves iron-dependent increase in lipid ROS and depletion of polyunsaturated fatty acids in plasma membranes [32]. Cisplatin was demonstrated to activate ferroptosis in HEIOC1 cells, leading to increased lipid peroxidation, iron accumulation and reduction of the mitochondrial membrane potential (MMP). A specific inhibitor of ferroptosis, ferrostatin-1 was shown to diminish cell death due to cisplatin in HEI-OC1 cells and in mouse cochlear explants by improving mitochondrial function [30,31]. Blockade of autophagy using chloroquine was found to ameliorate ferroptosis induced by cisplatin in HEI-O C1 cells, suggesting that the cell death induced by ferroptosis was associated with upregulation of autophagy [33]. However, targeting ferroptosis to prevent cisplatin induced hearing loss could be problematic, since ferroptosis is one of the mechanisms that underlie cisplatin induced killing of tumor cells [34]. Systemic treatment with a ferroptosis inhibitor could interfere with cisplatin efficacy to treat cancer. This could be avoided by using localized intratympanic administration of a ferroptosis inhibitor.

Cisplatin ototoxicity has also been associated with necroptosis. Necroptosis is a novel form of cell necrosis that serves as an alternative cell death pathway. It differs from necrotic cell death, which is passive. Rather it follows a program in cells that is mediated by the receptor-interacting protein kinases (RIPKs), RIPK1 and RIPK3. The intraperitoneal administration of Necrostatin-1s, a specific inhibitor of RIPK1 [35], protected mice against cisplatin induced hearing loss. Genetic inhibition of RIPK3 also protected against cisplatin ototoxicity in mice [36].

Oxidative stress can deplete the levels of antioxidant enzymes. Excess ROS production can also cause mitochondria to release cytochrome $\mathrm{c}$ which results in apoptosis [14]. Cisplatin also reduces the levels of antioxidant enzymes, including superoxide dismutase (SOD), glutathione reductase (GR), glutathione S-transferase (GST) and glutathione peroxidase (GSH-Px) [37,38].

Transient receptor potential (TRP) channels play an important role in mediating sensations, such as taste, touch and smell. They are also associated with neurogenic pain and inflammation [39-41]. These are nonselective cation permeable channels that can be activated by environmental or endogenous stimuli [42] including toxic reactive aldehydes [43] generated by cisplatin-mediated lipid peroxidation resulting from ROS generation. Several types of TRP channels have been identified in the cochlea [41]. TRPV1 channels are activated by oxidative stress, mediated by NOX3. NOX3 is activated by cisplatin leading to the production of ROS and TRPV1 upregulation. Knockdown of TRPV1 expression was achieved by transtympanic administration of TRPV1 siRNA. This protected against cisplatin-induced hearing loss. This protection was accompanied by reduced calcium influx and NOX3 expression, resulting in amelioration of ROS production, inflammation and apoptosis in the cochlea [40].

\section{Endogenous Antioxidant Defense System of the Cochlea}

Under normal conditions of auditory stimulation, ROS generated in the cochlea can be scavenged by an antioxidant defense system. This system consists of glutathione and enzymes that synthesize and regenerate glutathione and enzymes that detoxify ROS. ROS detoxification mechanisms are critical for protection of the cochlea since cisplatin produces excessive ROS in the cochlea that damage vulnerable cells by generating lipid peroxides, including malondialdehyde and 4-hydroxynonenal (4-HNE).

The highest levels of glutathione are present in the basal and intermediate cells of the stria vascularis and in the spiral ligament fibrocytes of the guinea pig cochlea [44] and are 
associated with the content of glutathione S-transferases [45]. Glutathione reductase and glutathione peroxidase (GPx) regenerate glutathione from its oxidized form. Glutathione-Stransferases are involved in cell detoxification. Of these, the glutathione transferase (GST) detoxification system converts a toxic compound into a less toxic form by conjugating the toxin to $\mathrm{SH}$ groups of reduced glutathione [46]. One of these enzymes, glutathione transferase $\alpha 4$ (GSTA4), has been shown to reduce cisplatin ototoxicity by detoxifying the toxic byproduct, 4-hydroxynonenal (4-HNE) in the cochlea of female mice [47].

Additional antioxidant enzymes are expressed in the cochlea. These include superoxide dismutases (SOD) and catalase (CAT). The SOD isoforms expressed in the cochlea include a cytosolic $\mathrm{Cu} / \mathrm{Zn}-\mathrm{SOD}$ isoform and a mitochondrial Mn-regulated isoform (MnSOD) [48]. The Mn-SOD isoform is found in the metabolically active tissues in the cochlea, including the lateral wall tissues (stria vascularis, spiral ligament, spiral prominence, spiral limbus and the organ of Corti [49]. CAT and GPx can detoxify $\mathrm{H}_{2} \mathrm{O}_{2}$. SOD and CAT act sequentially to reduce superoxide $\left(\mathrm{O}_{2}{ }^{-}\right)$to $\mathrm{O}_{2}$ and $\mathrm{H}_{2} \mathrm{O}$. Dismutation of $\mathrm{O}_{2}{ }^{-}$by superoxide dismutase (SOD) produces relatively more reactive molecule, hydrogen peroxide $\left(\mathrm{H}_{2} \mathrm{O}_{2}\right)$, which may be detoxified by CAT. However, if metal ions are present, the $\mathrm{H}_{2} \mathrm{O}_{2}$ may be converted into the more toxic and reactive hydroxyl radical $\left(\mathrm{OH}^{-}\right)$.

Additional antioxidant defense mechanisms are present in the cochlea. Vitamin C (ascorbic acid) is an endogenous antioxidant that has been shown to be present in cochlear fluid of guinea pigs in greater concentration than in plasma [50]. Cochlear oxidative stress can up-regulate kidney injury molecule-1 (KIM-1) which may help repair damaged cochlear tissue if it is not overwhelmed by cisplatin [51].

Heat shock proteins, including HSP-27, HSP32, HSP40, HSP60, HSP70 and HSP90 protects against cisplatin-induced hair cell death. These protective molecules not only inhibit apoptosis, but they also upregulate SOD [52,53].

Adult mouse utricles were cultured and subjected to heat shock. This treatment induced a strong up-regulation of HSP70 mRNA and a smaller increase in the expression of HSP90 and HSP27. The up-regulation of these HSPs resulted in protection of utricular cells against cisplatin induced cell death [53]. Another study subjected mouse utricular cultures to heat shock or transfection with adenovirus expressing HSP70. HSP70 was induced in glia-like supporting cells but not in hair cells. The induction of HSP70 prevented utricular hair cell death from cisplatin. Lovastatin appeared to protect the cochlea of cisplatin treated mice from ototoxicity by increasing the concentration of HSP60 and HSP32 mRNA in the cochlea [54]. The protective role of HSP32 (also known as heme oxygenase-1) against cisplatin ototoxicity was demonstrated in HEI-OC1 cells overexpressing the transcription factor, nuclear factor-erythroid factor 2-related factor 2 (Nrf2). This protection appeared to be mediated by PI3 kinase-AKT signaling that promoted heme oxygenase upregulation [55]. $\mathrm{Nrf} 2$ is a major regulator of cellular oxidative stress response and maintenance of redox homeostasis [56]. Nrf2 Activation has been shown to be otoprotective in HEI-OC1 cells in cisplatin-induced apoptosis [57]. The role of Nrf2/HO-1 pathway in hearing loss has been discussed in detail in several reviews [46,58-62].

Guinea pigs treated with cisplatin with or without pre-treatment with geranylgeranylacetone (GGA), inducer of HSPs [63], were compared for hearing loss and oxidative stress. Cisplatin treated animals had significantly greater shifts in ABR thresholds and greater NO and lipid peroxidation levels and had diminished expression of HSPs than those pretreated with GGA. The cochleae of guinea pigs treated GGA had reduced expression of NO and lipid peroxidation products and showed up-regulation of HSP27, HSP40 and HSP70. It appears that GGA protection against cisplatin ototoxicity is related to increased expression of these HSPs and that HSPs reduce oxidative stress in the cochlea caused by cisplatin [64].

\section{G-Proteins}

G-protein coupled receptors (GPCRs) are located in cell membranes and respond to various stimuli. Otoprotective GPCRs in the cochlea include $\mathrm{A}_{1}$ adenosine receptors $\left(\mathrm{A}_{1} \mathrm{AR}\right)$, cannabinoid receptor 2 (CB2) and sphingosine-1-phosphate receptor 2 (SIP2). 
$\mathrm{A}_{1} \mathrm{AR}$ have been demonstrated in the organ of Corti, stria vascularis and spiral ganglion cells [65]. In chinchilla, the A1AR agonist R-phenylisopropyladenosine (RPIA) activates these receptors and leads to increased activities of antioxidant enzymes, including GPx and SOD, in the cochlea [66]. Pretreatment with RPIA reduces cisplatin hearing loss by activation of A1AR causing decreased expression of NOX3 and activation of STAT1 which reduced oxidative stress and inflammation [67]. CB2 receptors have been demonstrated in the rat organ of Corti, stria vascularis and spiral ganglion neurites [68]. Local application of JWH-015, a CB2 agonist, significantly reduced OHC death, ABR threshold shifts and synaptopathy. Blockade of $\mathrm{CB} 2$ receptors alone produces hearing loss, suggesting that there may be tonic activation of CB2 receptors under normal conditions [68]. A specific S1P2 receptor agonist, CYM-5478, reduced cisplatin ototoxicity in rats [69]. The use of agonists for cochlear-specific GCPRs may provide be an effective clinical approach to ameliorating cisplatin induced hearing loss [70]. Cisplatin was found to induce the expression of the RGS17 gene leading to elevated levels of RGS17 protein. This contributed to hearing loss in rats. Conversely knockdown of RGS17 ameliorated hearing loss induced by cisplatin. Regulators of G protein signaling (RGS) increases the GTPase activity of G proteins to promptly terminate the activation of GPCRs. RGS 17 appears to contribute to cisplatin ototoxicity by uncoupling protective GPCRs, such as CB2, from their normal protective actions. RGS17 inhibitors could provide novel agents for ameliorating cisplatin induced hearing loss [71] by extending the period of activation of GPCR activation.

\section{Inflammation}

Cisplatin induces the production of pro-inflammatory cytokines, including tumor necrosis factor-alpha (TNF-alpha), interleukin-1- $\beta$ (IL-1 $\beta$ ) and nuclear factor kappa B (NF$\mathrm{kB}$ ) in the cochlea [55]. Cisplatin induced activation of NF-kB increases the production of more pro-inflammatory cytokines, leading to activation of caspases 3 and 9 , and increases in the expression of inducible nitric oxide synthase (iNOS). This leads to the production of the free radical nitric oxide (NO) [72]. The oral administration of flunarizine greatly attenuated pro-inflammatory cytokine increases in the cochlea and serum and diminished the expression of $N F-k B$ in the cochlea of cisplatin treated mice by activation of $\mathrm{Nrf} 2 /$ heme oxygenase-1 [55].

Cisplatin also induces the protein expression of signal transducer and activator of transcription-1 (STAT1) and down-regulates the expression of signal transducer and activator of transcription-3 (STAT3) in the cochlea [73]. ROS promote activation of STAT1 [74]. Activation of STAT1 in utricular hair cells in vitro promotes cell death [75]. Cisplatin increased the expression of COX-2, iNOS and TNF- $\alpha$ in rats. This increased inflammation in the cochlea leads to apoptosis of OHCs and loss of hearing $[67,73]$. STAT1 knockdown using siRNA in rats [67] or STAT1 ${ }^{-/}$mice [76] were protected against cisplatin ototoxicity.

STAT1 and STAT3 have opposing effects in the cochlea. STAT1 is pro-inflammatory and appears to mediate apoptosis in the cochlea resulting from cisplatin ototoxicity. STAT3 acts as a pro-survival molecule that helps to resolve inflammation [67,73]. Deletion of STAT3 sensitizes cells to oxidative stress [77]. STAT3 not only protects against oxidative stress, but it also up-regulates repair mechanisms for DNA damage [78]. Additional targets of STAT3 that promote survival are: the anti-apoptotic molecules Bcl-xL and Bcl-2 [79]. LMO4 targets STAT3 which confers pro-survival signals [80]. Cisplatin reduces the activity of LMO4 by nitration [28]. Animals deficient in LMO4 are more susceptible to cisplatin induced apoptosis in the cochlea and hearing loss [29]. The use of inhibitors for STAT1 to reduce cisplatin-induced inflammation and apoptosis may provide future treatments for cisplatin ototoxicity. In addition, the application of drugs to up-regulate STAT3 expression in the cochlea could promote cell survival pathways could provide novel therapeutic approaches to ameliorate cisplatin ototoxicity. 


\section{Current Treatments}

A wide variety of putative protective agents against cisplatin ototoxicity have been studied [70]. Antioxidant drugs have demonstrated protection against ototoxicity in animals treated with cisplatin [81]. Sodium thiosulfate reduced hearing loss in animal models with systemic administration. Unfortunately, systemically administered sodium thiosulfate reacts with cisplatin and reduces its anti-tumor activity [82]. Intratympanic injection avoids this problem [83]. Delayed administration of sodium thiosulfate has shown promise in clinical trials. This protective agent was administered intravenously in children with cancer $6 \mathrm{~h}$ after receiving cisplatin. This treatment showed significant reduction of the probability of hearing loss; however, patients with disseminated cancer were found to have a reduced survival rate [84]. In children with localized hepatoblastoma, the delayed administration of sodium thiosulfate $6 \mathrm{~h}$ after cisplatin reduced hearing loss without any discernible difference in survival [85]. A phase 3 clinical trial utilized cisplatin injection into the nutrient artery supplying the tumor in patients with locally advanced head and neck cancer. Sodium thiosulfate was injected in a different route (intravenously) at the same time. This group showed a 10\% decrease in hearing loss at the higher frequencies [86].

Another thiol compound, $\mathrm{N}$-acetylcysteine was effective in ameliorating hearing loss and cochlear damage in rats $[87,88]$. D-methionine, a sulfur-containing amino acid, was shown to be effective in reducing cisplatin ototoxicity when administered systemically [89] or locally $[83,90]$. The protection mediated by D-methionine appeared to be due to increased expression of antioxidant enzymes in the cochlea [91]. Other sulfur-containing antioxidants which showed efficacy against cisplatin-induced hearing loss in rats include lipoic acid, diethyldithiocarbamate and 4-methylthiobenzoic acid [92]. Amifostine is an organic thiophosphate cytoprotective agent. High doses of amifostine provided otoprotection in hamsters but its use was associated with neurotoxicity [93]. The selenium compound, ebselen is a glutathione peroxidase mimetic. Ebselen protected against cisplatin ototoxicity and nephrotoxicity in rats when combined with allopurinol [25].

Intratympanic administration of RPIA, an adenosine A1AR receptor agonist, increased the production of antioxidant enzymes (GSH-Px) and SOD in the cochlea [66] and protected OHCs from damage and prevented hearing loss [94] by reducing the expression of NOX3 ROS production and STAT1 mediated inflammation [67]. Cisplatin ototoxicity was also ameliorated by treatment with the adenosine amine congener (ADAC), acting via the A1AR [95].

Activation of CB2 receptors in the cochlea by intratympanic administration of JWH015, significantly protected against cisplatin induced hearing loss and OHC cell death and synaptopathy. This protective effect appeared to be mediated, in part, by inhibition of STAT1 [68].

It is critically important that any protective agent given to protect against cisplatin ototoxicity not interfere with the anti-tumor efficacy of cisplatin. A number of animal studies tested putative protective agents by intratympanic injection. Drugs such as steroids, etanercept, D- and L-methionine, pifithrin-alpha, adenosine agonists, melatonin, kenpaullone (a cyclin dependent kinase 2 [CDK2] inhibitor) have been reported to show efficacy against cisplatin ototoxicity in rodent models (reviewed in [96]. The administration of protective agents by this route would likely avoid inactivation of cisplatin in the systemic circulation.

It is encouraging to note that several studies utilizing systemic administration of protective agents have found amelioration of cisplatin ototoxicity in experimental animals without interference with its chemotherapeutic efficacy. Nude rats bearing HT-29 tumors received cisplatin in combination with a Src-protein kinase inhibitor. This co-treatment protected against cisplatin ototoxicity without compromising the efficacy of cisplatin in tumor response [97]. Oral $\beta$-lapachone ameliorated cisplatin ototoxicity. Cisplatin administration depleted intracellular $\mathrm{NAD}^{+}$and SIRT1 levels in the cochlea, but these levels were augmented by $\beta$-lapachone. $\beta$-lapachone decreased cochlear ROS production and DNA damage induced by cisplatin. $\beta$-lapachone was also found to reduce the production of pro-inflammatory cytokines in the cochlea by inhibiting NF-kB acetylation [98]. Cisplatin 
greatly increased the sensitivity of $\beta$-lapachone in suppressing the growth of leg tumors in mice [99]. Pifithrin-alpha is a p53 inhibitor that protected mice from ototoxicity without interference with cisplatin chemotherapeutic effectiveness and even sensitized p53-mutant tumors to cisplatin [13]. Epigallocatechin-3-gallate (EGCG), the polyphenol extract from green tea, was administered by oral gavage to cisplatin treated SCID mice bearing human head and neck squamous cell carcinoma cells. There was no evidence of interference of cisplatin anti-tumor efficacy [100]. Similar results were shown in tumor-bearing SCID mice treated with cisplatin and oral capsaicin. Tumor killing by cisplatin was not impaired by capsaicin co-treatment [73]. Honokiol, a polyphenol derived from Magnolia officinalis, ameliorated cisplatin ototoxicity in mice bearing mammary tumors were treated with cisplatin. Honokiol, did not interfere with the ability of cisplatin to effectively shrink the tumors and acted synergistically with cisplatin to reduce tumor size [101].

Intraperitoneal lovastatin injections prior to and after cisplatin administration protected against $\mathrm{ABR}$ threshold shifts and reduced $\mathrm{OHC}$ loss in mice. Lovastatin significantly increased the levels of the mRNA for heat shock proteins (HSP60 and HSP32/Hmox1) in the cochlea [54]. A very significant clinical trial compared head and neck cancer patients treated with cisplatin with or without concurrent atorvastatin. Those patients receiving atorvastatin had a significantly lower incidence of hearing loss compared to patients not receiving atorvastatin. Cancer patients on atorvastatin were found to be $53 \%$ less likely to suffer hearing loss compared to patients not taking a statin drug. Most important was the finding that 3 year survival rates were similar in both groups of patients [102].

\section{Future Directions}

There are several potential treatments to explore in the future for prevention of cisplatin ototoxicity. Animal studies which have shown drugs that protect against cisplatin ototoxicity without interfering with cisplatin efficacy should be considered for clinical trials. These include $\beta$-lapachone, honokiol, pifithrin alpha, EGCG, capsaicin, and a Src-protein kinase inhibitor.

Pediatric oncologists recommend trials of systemic rather than intratympanic route of treatment with protective agents against cisplatin [103]. A strong recommendation for continued use of systemic sodium thiosulfate in children with nonmetastatic hepatoblastoma was made. Further research to determine the safety of sodium thiosulfate in patients with metastatic cancer was encouraged [104]. For adults receiving cisplatin, the transtympanic approach appears to be attractive. However optimal dose, number of injections and clarifying what protectant is the safest and most effective would be important factors for consideration [105]. A novel formulation of sodium thiosulfate appears to be well tolerated and safe. Further studies are needed to determine its efficacy against cisplatin ototoxicity [106,107].

ORC-13661 is a novel high-affinity permeant blocker of the mechanoelectrical transducer (MET) channel in OHCs. In mouse cochlear cultures it provided significant protection of hair cells against cisplatin. It appears to be well tolerated in rats following oral administration [18]. Future studies should investigate whether this drug reduces cisplatin ototoxicity in mammalian models as it has been shown to protect rats against aminoglycoside ototoxicity [18].

Statins do not appear to interfere with cisplatin's anti-tumor effects in patients [102]. Additional clinical trials with statins should be carried out. $\beta$-lapachone appears to be safe and well-tolerated in early clinical trials of oral administration in healthy human volunteers [108]. It seems to be a promising agent for protecting against cisplatin ototoxicity and is worth considering for clinical trials.

Exosomes are membrane-bound nanovesicles that can be released from various cells in the body including supporting cells in the cochlea. They can provide HSPs to protect against cisplatin ototoxicity [109]. They could be used as nanocarriers to deliver drug treatments [109] or stem cells [110] to treat hearing loss from cisplatin 
chemotherapy. These nanovesicles appear to have great potential to protect against cisplatin induced hearing loss.

\section{Conclusions}

Cisplatin chemotherapy is associated with a very high incidence of irreversible sensorineural hearing loss. The drug gains access to the cochlea by several transport mechanisms, including the MET channels, which could serve as targets for treating ototoxicity as shown in Figure 1 and tabulated in Table 1. The generation of ROS and inflammation by cisplatin appear to be integral to mediating cisplatin ototoxicity. There are several novel agents that can protect against cisplatin ototoxicity. Some of these drugs have shown excellent protection of hearing without interfering with the therapeutic effect of cisplatin. The future looks bright and future clinical trials could bring much needed protection against cisplatin ototoxicity.

Table 1. Potential drugs and their targets for the treatment of cisplatin ototoxicity.

\begin{tabular}{|c|c|c|c|c|c|}
\hline & Experimental Drug & Mechanism of Action & Animal Model & $\begin{array}{c}\text { Route of } \\
\text { Administration }\end{array}$ & Reference \\
\hline 1 & Amifostine & Free radical scavenger & Hamster & Intraperitoneal & [93] \\
\hline 2 & Atorvastatin & $\begin{array}{l}\text { Commonly used drug for } \\
\text { management of } \\
\text { hypercholesterolemia by } \\
\text { inhibition of 3-hydroxy-3- } \\
\text { methylglutaryl-CoA } \\
\text { (HMG-CoA) enzyme }\end{array}$ & Human & Oral & [102] \\
\hline 3 & $\beta$-Lapachone (NAD+) & Anti-oxidant & Rat & Oral & [98] \\
\hline 4 & Capsaicin & $\begin{array}{l}\text { TRPV1 agonist that } \\
\text { desensitizes } \\
\text { CB2R agonist }\end{array}$ & Rat & Oral & [73] \\
\hline 5 & CYM-5478 & SIP-2 receptor agonist & Rat & Intraperitoneal & [69] \\
\hline 6 & D-Methionine (D-Met) & Anti-oxidant molecule & Rat & Intraperitoneal & [89] \\
\hline 7 & Ebselen & $\begin{array}{l}\text { Glutathione peroxidase } \\
\text { mimetic }\end{array}$ & Rat & Oral & {$[25,111]$} \\
\hline 8 & EGCG & STAT1 inhibition & Rat & Oral & [100] \\
\hline 9 & Flunarizine & Nrf2 activation & Mice & Oral & [55] \\
\hline 10 & GGA & Inducer of HSPs & Guinea pig & Systemic & [64] \\
\hline 11 & Honokiol & Anti-oxidant & Mice & Intraperitoneal & [101] \\
\hline 12 & $\begin{array}{l}\text { JWH-015, (2-methyl-1- } \\
\text { propyl-1H-indol-3-yl)-1- } \\
\text { naphthalenylmethanone) }\end{array}$ & CB2R agonist & Rat & Intratympanic & [68] \\
\hline 13 & N-acetylcysteine & Anti-oxidant & Rat & Intravenous & [87] \\
\hline 14 & Lovastatin & $\begin{array}{l}\text { Commonly used drug for } \\
\text { management of } \\
\text { hypercholesterolemia by } \\
\text { inhibition of 3-hydroxy-3- } \\
\text { methylglutaryl-CoA } \\
\text { (HMG-CoA) enzyme }\end{array}$ & Mice & Oral Gavage & [54] \\
\hline 15 & Pifithrin- $\alpha$ & p53 inhibitor & Mice & Intraperitoneal & [13] \\
\hline 16 & RPIA, ADAC & A1AR agonist & Rat & Intratympanic & {$[67,95]$} \\
\hline 17 & STAT1 siRNA & Anti-inflammatory & Rat & Intratympanic & [112] \\
\hline
\end{tabular}


Table 1. Cont.

\begin{tabular}{|c|c|c|c|c|c|}
\hline & perimental Drug & Mechanism of Action & Animal Model & $\begin{array}{c}\text { Route of } \\
\text { Administration }\end{array}$ & Reference \\
\hline 18 & TRPV1 siRNA & Anti-inflammatory & Rat & Intratympanic & [40] \\
\hline 19 & Sodium thiosulphate & Anti-oxidant & $\begin{array}{l}\text { Guinea pig } \\
\text { Humans }\end{array}$ & $\begin{array}{l}\text { Round window } \\
\text { administration }\end{array}$ & $\begin{array}{c}{[83]} \\
{[104]}\end{array}$ \\
\hline
\end{tabular}

Funding: The authors were funded by the National Institute on Deafness and Other Communication Disorders [grant numbers: R01DC002396, R01DC016835 and R43DC018258.

Conflicts of Interest: The authors declare no conflict of interest.

\section{References}

1. Laurell, G. Pharmacological intervention in the field of ototoxicity. HNO 2019, 67, 434-439. [CrossRef] [PubMed]

2. Bertolini, P.; Lassalle, M.; Mercier, G.; Raquin, M.A.; Izzi, G.; Corradini, N.; Hartmann, O. Platinum Compound-Related Ototoxicity in Children: Long-Term Follow-Up Reveals Continuous Worsening of Hearing Loss. J. Pediatr. Hematol. Oncol. 2004, 26, 649-655. [CrossRef]

3. Meijer, A.J.M.; Li, K.H.; Brooks, B.; Clemens, E.; Ross, C.J.; Rassekh, S.R.; Hoetink, A.E.; van Grotel, M.; van den Heuvel-Eibrink, M.M.; Carleton, B.C. The cumulative incidence of cisplatin-induced hearing loss in young children is higher and develops at an early stage during therapy compared with older children based on 2052 audiological assessments. Cancer 2021. [CrossRef] [PubMed]

4. Breglio, A.M.; Rusheen, A.E.; Shide, E.D.; Fernandez, K.A.; Spielbauer, K.K.; McLachlin, K.M.; Hall, M.D.; Amable, L.; Cunningham, L.L. Cisplatin is retained in the cochlea indefinitely following chemotherapy. Nat. Commun. 2017, 8, 1654. [CrossRef] [PubMed]

5. Schweitzer, V.G. Ototoxicity of chemotherapeutic agents. Otolaryngol. Clin. N. Am. 1993, 26, 759-789. [CrossRef]

6. Comis, S.D.; Rhys-Evans, P.H.; Osborne, M.P.; Pickles, J.O.; Jeffries, D.J.; Pearse, H.A. Early morphological and chemical changes induced by cisplatin in the guinea pig organ of Corti. J. Laryngol. Otol. 1986, 100, 1375-1383. [CrossRef] [PubMed]

7. Meech, R.P.; Campbell, K.C.; Hughes, L.P.; Rybak, L.P. A semiquantitative analysis of the effects of cisplatin on the rat stria vascularis. Hear Res. 1998, 124, 44-59. [CrossRef]

8. Binks, S.; Dobrota, M. Kinetics and mechanism of uptake of platinum-based pharmaceuticals by the rat small intestine. Biochem. Pharmacol. 1990, 40, 1329-1336. [CrossRef]

9. Burger, H.; Loos, W.J.; Eechoute, K.; Verweij, J.; Mathijssen, R.H.; Wiemer, E.A. Drug transporters of platinum-based anticancer agents and their clinical significance. Drug Resist. Updates 2011, 14, 22-34. [CrossRef]

10. More, S.S.; Akil, O.; Ianculescu, A.G.; Geier, E.G.; Lustig, L.R.; Giacomini, K.M. Role of the copper transporter, CTR1, in platinum-induced ototoxicity. J. Neurosci. 2010, 30, 9500-9509. [CrossRef]

11. Ciarimboli, G.; Deuster, D.; Knief, A.; Sperling, M.; Holtkamp, M.; Edemir, B.; Pavenstadt, H.; Lanvers-Kaminsky, C.; am Zehnhoff-Dinnesen, A.; Schinkel, A.H.; et al. Organic cation transporter 2 mediates cisplatin-induced oto- and nephrotoxicity and is a target for protective interventions. Am. J. Pathol. 2010, 176, 1169-1180. [CrossRef]

12. Ekborn, A.; Lindberg, A.; Laurell, G.; Wallin, I.; Eksborg, S.; Ehrsson, H. Ototoxicity, nephrotoxicity and pharmacokinetics of cisplatin and its monohydrated complex in the guinea pig. Cancer Chemother. Pharmacol. 2003, 51, 36-42. [CrossRef]

13. Benkafadar, N.; Menardo, J.; Bourien, J.; Nouvian, R.; Francois, F.; Decaudin, D.; Maiorano, D.; Puel, J.L.; Wang, J. Reversible p53 inhibition prevents cisplatin ototoxicity without blocking chemotherapeutic efficacy. EMBO Mol. Med. 2017, 9, 7-26. [CrossRef]

14. Wang, J.; Ladrech, S.; Pujol, R.; Brabet, P.; Van De Water, T.R.; Puel, J.L. Caspase inhibitors, but not c-Jun NH2-terminal kinase inhibitor treatment, prevent cisplatin-induced hearing loss. Cancer Res. 2004, 64, 9217-9224. [CrossRef]

15. Kimitsuki, T.; Nakagawa, T.; Hisashi, K.; Komune, S.; Komiyama, S. Cisplatin blocks mechano-electric transducer current in chick cochlear hair cells. Hear. Res. 1993, 71, 64-68. [CrossRef]

16. McAlpine, D.; Johnstone, B.M. The ototoxic mechanism of cisplatin. Hear. Res. 1990, 47, 191-203. [CrossRef]

17. Thomas, A.J.; Hailey, D.W.; Stawicki, T.M.; Wu, P.; Coffin, A.B.; Rubel, E.W.; Raible, D.W.; Simon, J.A.; Ou, H.C. Functional mechanotransduction is required for cisplatin-induced hair cell death in the zebrafish lateral line. J. Neurosci. 2013, 33, 4405-4414. [CrossRef]

18. Kitcher, S.R.; Kirkwood, N.K.; Camci, E.D.; Wu, P.; Gibson, R.M.; Redila, V.A.; Simon, J.A.; Rubel, E.W.; Raible, D.W.; Richardson, G.P.; et al. ORC-13661 protects sensory hair cells from aminoglycoside and cisplatin ototoxicity. JCI Insight 2019, 4, e126764. [CrossRef]

19. Beurg, M.; ui, R.; Goldring, A.C.; Ebrahim, S.; Fettiplace, R.; Kachar, B. Variable number of TMC1-dependent mechanotransducer channels underlie tonotopic conductance gradients in the cochlea. Nat. Commun. 2018, 9, 2185. [CrossRef]

20. Kopke, R.D.; Liu, W.; Gabaizadeh, R.; Jacono, A.; Feghali, J.; Spray, D.; Garcia, P.; Steinman, H.; Malgrange, B.; Ruben, R.J.; et al. Use of organotypic cultures of Corti's organ to study the protective effects of antioxidant molecules on cisplatin-induced damage of auditory hair cells. Am. J. Otol. 1997, 18, 559-571. 
21. Clerici, W.J.; Hensley, K.; DiMartino, D.L.; Butterfield, D.A. Direct detection of ototoxicant-induced reactive oxygen species generation in cochlear explants. Hear. Res. 1996, 98, 116-124. [CrossRef]

22. Banfi, B.; Malgrange, B.; Knisz, J.; Steger, K.; Dubois-Dauphin, M.; Krause, K.H. NOX3, a superoxide-generating NADPH oxidase of the inner ear. J. Biol. Chem. 2004, 279, 46065-46072. [CrossRef] [PubMed]

23. Mukherjea, D.; Jajoo, S.; Sheehan, K.; Kaur, T.; Sheth, S.; Bunch, J.; Perro, C.; Rybak, L.P.; Ramkumar, V. NOX3 NADPH oxidase couples transient receptor potential vanilloid 1 to signal transducer and activator of transcription 1-mediated inflammation and hearing loss. Antioxid. Redox Signal. 2011, 14, 999-1010. [CrossRef] [PubMed]

24. Mohri, H.; Ninoyu, Y.; Sakaguchi, H.; Hirano, S.; Saito, N.; Ueyama, T. Nox3-Derived Superoxide in Cochleae Induces Sensorineural Hearing Loss. J. Neurosci. 2021, 41, 4716-4731. [CrossRef]

25. Lynch, E.D.; Gu, R.; Pierce, C.; Kil, J. Reduction of acute cisplatin ototoxicity and nephrotoxicity in rats by oral administration of allopurinol and ebselen. Hear. Res. 2005, 201, 81-89. [CrossRef]

26. Watanabe, K.; Inai, S.; Jinnouchi, K.; Bada, S.; Hess, A.; Michel, O.; Yagi, T. Nuclear-factor kappa B (NF-kappa B)-inducible nitric oxide synthase (iNOS/NOS II) pathway damages the stria vascularis in cisplatin-treated mice. Anticancer Res. 2002, 22, 4081-4085.

27. Li, G.; Liu, W.; Frenz, D. Cisplatin ototoxicity to the rat inner ear: A role for HMG1 and iNOS. Neurotoxicology 2006, 27, 22-30. [CrossRef]

28. Jamesdaniel, S.; Coling, D.; Hinduja, S.; Ding, D.; Li, J.; Cassidy, L.; Seigel, G.M.; Qu, J.; Salvi, R. Cisplatin-induced ototoxicity is mediated by nitroxidative modification of cochlear proteins characterized by nitration of Lmo4. J. Biol. Chem. 2012, 287, 18674-18686. [CrossRef]

29. Rosati, R.; Shahab, M.; Ramkumar, V.; Jamesdaniel, S. Lmo4 Deficiency Enhances Susceptibility to Cisplatin-Induced Cochlear Apoptosis and Hearing Loss. Mol. Neurobiol. 2021, 58, 2019-2029. [CrossRef]

30. Hu, B.; Liu, Y.; Chen, X.; Zhao, J.; Han, J.; Dong, H.; Zheng, Q.; Nie, G. Ferrostatin-1 protects auditory hair cells from cisplatininduced ototoxicity in vitro and in vivo. Biochem. Biophys. Res. Commun. 2020, 533, 1442-1448. [CrossRef]

31. Mei, H.; Zhao, L.; Li, W.; Zheng, Z.; Tang, D.; Lu, X.; He, Y. Inhibition of ferroptosis protects House Ear Institute-Organ of Corti 1 cells and cochlear hair cells from cisplatin-induced ototoxicity. J. Cell. Mol. Med. 2020, 24, 12065-12081. [CrossRef]

32. Cao, J.Y.; Dixon, S.J. Mechanisms of ferroptosis. Cell. Mol. Life Sci. 2016, 73, 2195-2209. [CrossRef]

33. Jian, B.; Pang, J.; Xiong, H.; Zhang, W.; Zhan, T.; Su, Z.; Lin, H.; Zhang, H.; He, W.; Zheng, Y. Autophagy-dependent ferroptosis contributes to cisplatin-induced hearing loss. Toxicol. Lett. 2021, 350, 249-260. [CrossRef]

34. Guo, J.; Xu, B.; Han, Q.; Zhou, H.; Xia, Y.; Gong, C.; Dai, X.; Li, Z.; Wu, G. Ferroptosis: A Novel Anti-tumor Action for Cisplatin. Cancer Res. Treat. 2018, 50, 445-460. [CrossRef]

35. Degterev, A.; Huang, Z.; Boyce, M.; Li, Y.; Jagtap, P.; Mizushima, N.; Cuny, G.D.; Mitchison, T.J.; Moskowitz, M.A.; Yuan, J. Chemical inhibitor of nonapoptotic cell death with therapeutic potential for ischemic brain injury. Nat. Chem. Biol. 2005, 1, 112-119. [CrossRef]

36. Ruhl, D.; Du, T.T.; Wagner, E.L.; Choi, J.H.; Li, S.; Reed, R.; Kim, K.; Freeman, M.; Hashisaki, G.; Lukens, J.R.; et al. Necroptosis and Apoptosis Contribute to Cisplatin and Aminoglycoside Ototoxicity. J. Neurosci. 2019, 39, 2951-2964. [CrossRef]

37. Campbell, K.C.; Meech, R.P.; Rybak, L.P.; Hughes, L.F. The effect of D-methionine on cochlear oxidative state with and without cisplatin administration: Mechanisms of otoprotection. J. Am. Acad. Audiol. 2003, 14, 144-156. [CrossRef]

38. Rybak, L.P.; Husain, K.; Morris, C.; Whitworth, C.; Somani, S. Effect of protective agents against cisplatin ototoxicity. Am. J. Otol. 2000, 21, 513-520.

39. Bujak, J.K.; Kosmala, D.; Szopa, I.M.; Majchrzak, K.; Bednarczyk, P. Inflammation, Cancer and Immunity-Implication of TRPV1 Channel. Front. Oncol. 2019, 9, 1087. [CrossRef]

40. Mukherjea, D.; Jajoo, S.; Whitworth, C.; Bunch, J.R.; Turner, J.G.; Rybak, L.P.; Ramkumar, V. Short interfering RNA against transient receptor potential vanilloid 1 attenuates cisplatin-induced hearing loss in the rat. J. Neurosci. 2008, 28, 13056-13065. [CrossRef]

41. Ramkumar, V.; Sheth, S.; Dhukhwa, A.; Al Aameri, R.; Rybak, L.P.; Mukherjea, D. Transient Receptor Potential (TRP) Channels and Auditory Functions. Antioxid. Redox Signal. 2021. [CrossRef]

42. Damann, N.; Voets, T.; Nilius, B. TRPs in our senses. Curr. Biol. 2008, 18, R880-9. [CrossRef]

43. Hellenthal, K.E.M.; Brabenec, L.; Gross, E.R.; Wagner, N.-M. TRP Channels as Sensors of Aldehyde and Oxidative Stress. Biomolecules 2021, 11, 1401. [CrossRef] [PubMed]

44. Usami, S.; Hjelle, O.; Ottersen, O. Differential cellular distribution of glutathione-an endogenous antioxidant-in the guinea pig inner ear. Brain Res. 1996, 743, 337-340. [CrossRef]

45. el Barbary, A.; Altschuler, R.A.; Schacht, J. Glutathione S-transferases in the organ of Corti of the rat: Enzymatic activity, subunit composition and immunohistochemical localization. Hear. Res. 1993, 71, 80-90. [CrossRef]

46. Someya, S.; Kim, M.J. Cochlear detoxification: Role of alpha class glutathione transferases in protection against oxidative lipid damage, ototoxicity, and cochlear aging. Hear. Res. 2021, 402, 108002. [CrossRef] [PubMed]

47. Park, H.J.; Kim, M.J.; Rothenberger, C.; Kumar, A.; Sampson, E.M.; Ding, D.; Han, C.; White, K.; Boyd, K.; Manohar, S.; et al. GSTA4 mediates reduction of cisplatin ototoxicity in female mice. Nat. Commun. 2019, 10, 4150. [CrossRef]

48. Yao, X.; Rarey, K.E. Detection and regulation of Cu/Zn-SOD and Mn-SOD in rat cochlear tissues. Hear. Res 1996, 96, 199-203. [CrossRef] 
49. Lai, M.T.; Ohmichi, T.; Egusa, K.; Okada, S.; Masuda, Y. Immunohistochemical localization of manganese superoxide dismutase in the rat cochlea. Eur. Arch. Otorhinolaryngol. 1996, 253, 273-277. [CrossRef]

50. Fujita, T.; Yamashita, D.; Irino, Y.; Kitamoto, J.; Fukuda, Y.; Inokuchi, G.; Hasegawa, S.; Otsuki, N.; Yoshida, M.; Nibu, K. Metabolomic profiling in inner ear fluid by gas chromatography/mass spectrometry in guinea pig cochlea. Neurosci. Lett. 2015, 606, 188-193. [CrossRef]

51. Mukherjea, D.; Whitworth, C.A.; Nandish, S.; Dunaway, G.A.; Rybak, L.P.; Ramkumar, V. Expression of the kidney injury molecule 1 in the rat cochlea and induction by cisplatin. Neuroscience 2006, 139, 733-740. [CrossRef]

52. Moriyama-Gonda, N.; Igawa, M.; Shiina, H.; Urakami, S.; Shigeno, K.; Terashima, M. Modulation of heat-induced cell death in PC-3 prostate cancer cells by the antioxidant inhibitor diethyldithiocarbamate. BJU Int. 2002, 90, 317-325. [CrossRef]

53. Cunningham, L.L.; Brandon, C.S. Heat shock inhibits both aminoglycoside- and cisplatin-induced sensory hair cell death. J. Assoc. Res. Otolaryngol. 2006, 7, 299-307. [CrossRef]

54. Fernandez, K.; Spielbauer, K.K.; Rusheen, A.; Wang, L.; Baker, T.G.; Eyles, S.; Cunningham, L.L. Lovastatin protects against cisplatin-induced hearing loss in mice. Hear. Res. 2020, 389, 107905. [CrossRef]

55. So, H.; Kim, H.; Kim, Y.; Kim, E.; Pae, H.O.; Chung, H.T.; Kim, H.J.; Kwon, K.B.; Lee, K.M.; Lee, H.Y.; et al. Evidence that cisplatin-induced auditory damage is attenuated by downregulation of pro-inflammatory cytokines via Nrf2/HO-1. J. Assoc. Res. Otolaryngol. 2008, 9, 290-306. [CrossRef]

56. Ma, Q. Role of nrf2 in oxidative stress and toxicity. Annu. Rev. Pharmacol. Toxicol. 2013, 53, 401-426. [CrossRef]

57. Zhang, W.; Xiong, H.; Pang, J.; Su, Z.; Lai, L.; Lin, H.; Jian, B.; He, W.; Yang, H.; Zheng, Y. Nrf2 activation protects auditory hair cells from cisplatin-induced ototoxicity independent on mitochondrial ROS production. Toxicol. Lett. 2020, 331, 1-10. [CrossRef]

58. Fetoni, A.R.; Paciello, F.; Rolesi, R.; Paludetti, G.; Troiani, D. Targeting dysregulation of redox homeostasis in noise-induced hearing loss: Oxidative stress and ROS signaling. Free Radic. Biol. Med. 2019, 135, 46-59. [CrossRef] [PubMed]

59. Honkura, Y.; Matsuo, H.; Murakami, S.; Sakiyama, M.; Mizutari, K.; Shiotani, A.; Yamamoto, M.; Morita, I.; Shinomiya, N.; Kawase, T.; et al. NRF2 Is a Key Target for Prevention of Noise-Induced Hearing Loss by Reducing Oxidative Damage of Cochlea. Sci. Rep. 2016, 6, 19329. [CrossRef]

60. Prasad, K.N.; Bondy, S.C. Increased oxidative stress, inflammation, and glutamate: Potential preventive and therapeutic targets for hearing disorders. Mech. Ageing Dev. 2020, 185, 111191. [CrossRef]

61. Eshraghi, A.A.; Jung, H.D.; Mittal, R. Recent Advancements in Gene and Stem Cell-Based Treatment Modalities: Potential Implications in Noise-Induced Hearing Loss. Anat. Rec. 2020, 303, 516-526. [CrossRef] [PubMed]

62. Li, D.; Zhao, H.; Cui, Z.K.; Tian, G. The Role of Nrf2 in Hearing Loss. Front. Pharmacol. 2021, 12, 620921. [CrossRef] [PubMed]

63. Hirakawa, T.; Rokutan, K.; Nikawa, T.; Kishi, K. Geranylgeranylacetone induces heat shock proteins in cultured guinea pig gastric mucosal cells and rat gastric mucosa. Gastroenterology 1996, 111, 345-357. [CrossRef]

64. Lo, W.C.; Wu, C.T.; Lee, H.C.; Young, Y.H.; Chang, Y.L.; Cheng, P.W. Evaluation of geranylgeranylacetone against cisplatininduced ototoxicity by auditory brainstem response, heat shock proteins and oxidative levels in guinea pigs. Neurotoxicol. Teratol. 2017, 61, 29-35. [CrossRef]

65. Vlajkovic, S.M.; Housley, G.D.; Thorne, P.R. Adenosine and the auditory system. Curr. Neuropharmacol. 2009, 7, $246-256$. [CrossRef]

66. Ford, M.S.; Maggirwar, S.B.; Rybak, L.P.; Whitworth, C.; Ramkumar, V. Expression and function of adenosine receptors in the chinchilla cochlea. Hear. Res. 1997, 105, 130-140. [CrossRef]

67. Kaur, T.; Borse, V.; Sheth, S.; Sheehan, K.; Ghosh, S.; Tupal, S.; Jajoo, S.; Mukherjea, D.; Rybak, L.P.; Ramkumar, V. Adenosine A1 Receptor Protects Against Cisplatin Ototoxicity by Suppressing the NOX3/STAT1 Inflammatory Pathway in the Cochlea. J. Neurosci. 2016, 36, 3962-3977. [CrossRef]

68. Ghosh, S.; Sheth, S.; Sheehan, K.; Mukherjea, D.; Dhukhwa, A.; Borse, V.; Rybak, L.P.; Ramkumar, V. The Endocannabinoid/Cannabinoid Receptor 2 System Protects Against Cisplatin-Induced Hearing Loss. Front. Cell. Neurosci. 2018, $12,271$. [CrossRef]

69. Wang, W.; Shanmugam, M.K.; Xiang, P.; Yam, T.Y.A.; Kumar, V.; Chew, W.S.; Chang, J.K.; Ali, M.Z.B.; Reolo, M.J.Y.; Peh, Y.X.; et al Sphingosine 1-Phosphate Receptor 2 Induces Otoprotective Responses to Cisplatin Treatment. Cancers 2020, 12, 211. [CrossRef]

70. Mukherjea, D.; Dhukhwa, A.; Sapra, A.; Bhandari, P.; Woolford, K.; Franke, J.; Ramkumar, V.; Rybak, L. Strategies to reduce the risk of platinum containing antineoplastic drug-induced ototoxicity. Expert Opin. Drug Metab. Toxicol. 2020, 16, 965-982. [CrossRef]

71. Dhukhwa, A.; Al Aameri, R.F.H.; Sheth, S.; Mukherjea, D.; Rybak, L.; Ramkumar, V. Regulator of G protein signaling 17 represents a novel target for treating cisplatin induced hearing loss. Sci. Rep. 2021, 11, 8116. [CrossRef]

72. Hazlitt, R.A.; Min, J.; Zuo, J. Progress in the Development of Preventative Drugs for Cisplatin-Induced Hearing Loss. J. Med. Chem. 2018, 61, 5512-5524. [CrossRef]

73. Bhatta, P.; Dhukhwa, A.; Sheehan, K.; Al Aameri, R.F.H.; Borse, V.; Ghosh, S.; Sheth, S.; Mamillapalli, C.; Rybak, L.; Ramkumar, V.; et al. Capsaicin Protects Against Cisplatin Ototoxicity by Changing the STAT3/STAT1 Ratio and Activating Cannabinoid (CB2) Receptors in the Cochlea. Sci. Rep. 2019, 9, 4131. [CrossRef]

74. Stephanou, A.; Brar, B.K.; Scarabelli, T.M.; Jonassen, A.K.; Yellon, D.M.; Marber, M.S.; Knight, R.A.; Latchman, D.S. Ischemiainduced STAT-1 expression and activation play a critical role in cardiomyocyte apoptosis. J. Biol. Chem. 2000, 275, 10002-10008. [CrossRef] 
75. Schmitt, N.C.; Rubel, E.W.; Nathanson, N.M. Cisplatin-induced hair cell death requires STAT1 and is attenuated by epigallocatechin gallate. J. Neurosci. 2009, 29, 3843-3851. [CrossRef] [PubMed]

76. Levano, S.; Bodmer, D. Loss of STAT1 protects hair cells from ototoxicity through modulation of STAT3, c-Jun, Akt, and autophagy factors. Cell Death Dis. 2015, 6, e2019. [CrossRef] [PubMed]

77. Barry, S.P.; Townsend, P.A.; McCormick, J.; Knight, R.A.; Scarabelli, T.M.; Latchman, D.S.; Stephanou, A. STAT3 deletion sensitizes cells to oxidative stress. Biochem. Biophys. Res. Commun. 2009, 385, 324-329. [CrossRef]

78. Barry, S.P.; Townsend, P.A.; Knight, R.A.; Scarabelli, T.M.; Latchman, D.S.; Stephanou, A. STAT3 modulates the DNA damage response pathway. Int. J. Exp. Pathol. 2010, 91, 506-514. [CrossRef]

79. Snyder, M.; Huang, X.Y.; Zhang, J.J. Identification of novel direct Stat3 target genes for control of growth and differentiation. J. Biol. Chem. 2008, 283, 3791-3798. [CrossRef]

80. Hilfiker-Kleiner, D.; Hilfiker, A.; Fuchs, M.; Kaminski, K.; Schaefer, A.; Schieffer, B.; Hillmer, A.; Schmiedl, A.; Ding, Z.; Podewski, E.; et al. Signal transducer and activator of transcription 3 is required for myocardial capillary growth, control of interstitial matrix deposition, and heart protection from ischemic injury. Circ. Res. 2004, 95, 187-195. [CrossRef]

81. Sheth, S.; Mukherjea, D.; Rybak, L.P.; Ramkumar, V. Mechanisms of Cisplatin-Induced Ototoxicity and Otoprotection. Front. Cell. Neurosci. 2017, 11, 338. [CrossRef]

82. Wimmer, C.; Mees, K.; Stumpf, P.; Welsch, U.; Reichel, O.; Suckfull, M. Round window application of D-methionine, sodium thiosulfate, brain-derived neurotrophic factor, and fibroblast growth factor-2 in cisplatin-induced ototoxicity. Otol. Neurotol. 2004, 25, 33-40. [CrossRef]

83. Wang, J.; Lloyd Faulconbridge, R.V.; Fetoni, A.; Guitton, M.J.; Pujol, R.; Puel, J.L. Local application of sodium thiosulfate prevents cisplatin-induced hearing loss in the guinea pig. Neuropharmacology 2003, 45, 380-393. [CrossRef]

84. Freyer, D.R.; Chen, L.; Krailo, M.D.; Knight, K.; Villaluna, D.; Bliss, B.; Pollock, B.H.; Ramdas, J.; Lange, B.; Van Hoff, D.; et al. Effects of sodium thiosulfate versus observation on development of cisplatin-induced hearing loss in children with cancer (ACCL0431): A multicentre, randomised, controlled, open-label, phase 3 trial. Lancet Oncol. 2017, 18, 63-74. [CrossRef]

85. Brock, P.R.; Maibach, R.; Childs, M.; Rajput, K.; Roebuck, D.; Sullivan, M.J.; Laithier, V.; Ronghe, M.; Dall'Igna, P.; Hiyama, E.; et al. Sodium Thiosulfate for Protection from Cisplatin-Induced Hearing Loss. N. Engl. J. Med. 2018, 378, 2376-2385. [CrossRef] [PubMed]

86. Zuur, C.L.; Simis, Y.J.; Lansdaal, P.E.; Hart, A.A.; Rasch, C.R.; Schornagel, J.H.; Dreschler, W.A.; Balm, A.J. Risk factors of ototoxicity after cisplatin-based chemo-irradiation in patients with locally advanced head-and-neck cancer: A multivariate analysis. Int. J. Radiat. Oncol. Biol. Phys. 2007, 68, 1320-1325. [CrossRef]

87. Thomas Dickey, D.; Muldoon, L.L.; Kraemer, D.F.; Neuwelt, E.A. Protection against cisplatin-induced ototoxicity by Nacetylcysteine in a rat model. Hear. Res. 2004, 193, 25-30. [CrossRef]

88. Somdas, M.A.; Gunturk, I.; Balcioglu, E.; Avci, D.; Yazici, C.; Ozdamar, S. Protective effect of N-acetylcysteine against cisplatin ototoxicity in rats: A study with hearing tests and scanning electron microscopy. Braz. J. Otorhinolaryngol. 2020, 86, 30-37. [CrossRef]

89. Campbell, K.C.; Rybak, L.P.; Meech, R.P.; Hughes, L. D-methionine provides excellent protection from cisplatin ototoxicity in the rat. Hear. Res. 1996, 102, 90-98. [CrossRef]

90. Korver, K.D.; Rybak, L.P.; Whitworth, C.; Campbell, K.M. Round window application of D-methionine provides complete cisplatin otoprotection. Otolaryngol. Head Neck Surg. 2002, 126, 683-689. [CrossRef]

91. Campbell, K.C.; Meech, R.P.; Klemens, J.J.; Gerberi, M.T.; Dyrstad, S.S.; Larsen, D.L.; Mitchell, D.L.; El-Azizi, M.; Verhulst, S.J.; Hughes, L.F. Prevention of noise- and drug-induced hearing loss with D-methionine. Hear. Res. 2007, 226, 92-103. [CrossRef]

92. Rybak, L.; Somani, S. Ototoxicity Amelioration by protective agents. Ann. N. Y. Acad. Sci. 1999, 884, $143-151$.

93. Church, M.W.; Blakley, B.W.; Burgio, D.L.; Gupta, A.K. WR-2721 (Amifostine) ameliorates cisplatin-induced hearing loss but causes neurotoxicity in hamsters: Dose-dependent effects. J. Assoc. Res. Otolaryngol. 2004, 5, 227-237. [CrossRef]

94. Whitworth, C.A.; Ramkumar, V.; Jones, B.; Tsukasaki, N.; Rybak, L.P. Protection against cisplatin ototoxicity by adenosine agonists. Biochem. Pharmacol. 2004, 67, 1801-1807. [CrossRef] [PubMed]

95. Gunewardene, N.; Guo, C.; Wong, A.C.; Thorne, P.R.; Vlajkovic, S.M. Adenosine amine congener ameliorates cisplatin-induced hearing loss. World J. Otorhinolaryngol. 2013, 3, 100-107. [CrossRef]

96. Rybak, L.P.; Dhukhwa, A.; Mukherjea, D.; Ramkumar, V. Local Drug Delivery for Prevention of Hearing Loss. Front. Cell. Neurosci. 2019, 13, 300. [CrossRef] [PubMed]

97. Bielefeld, E.C.; Tanaka, C.; Chen, G.D.; Coling, D.; Li, M.; Henderson, D.; Fetoni, A.R. An Src-protein tyrosine kinase inhibitor to reduce cisplatin ototoxicity while preserving its antitumor effect. Anticancer Drugs 2013, 24, 43-51. [CrossRef]

98. Kim, H.J.; Oh, G.S.; Shen, A.; Lee, S.B.; Choe, S.K.; Kwon, K.B.; Lee, S.; Seo, K.S.; Kwak, T.H.; Park, R.; et al. Augmentation of $\mathrm{NAD}(+)$ by NQO1 attenuates cisplatin-mediated hearing impairment. Cell Death Dis. 2014, 5, e1292. [CrossRef]

99. Terai, K.; Dong, G.Z.; Oh, E.T.; Park, M.T.; Gu, Y.; Song, C.W.; Park, H.J. Cisplatin enhances the anticancer effect of beta-lapachone by upregulating NQO1. Anticancer Drugs 2009, 20, 901-909. [CrossRef]

100. Borse, V.; Al Aameri, R.F.H.; Sheehan, K.; Sheth, S.; Kaur, T.; Mukherjea, D.; Tupal, S.; Lowy, M.; Ghosh, S.; Dhukhwa, A.; et al. Epigallocatechin-3-gallate, a prototypic chemopreventative agent for protection against cisplatin-based ototoxicity. Cell Death Dis. 2017, 8, e2921. [CrossRef]

101. Tan, X.; Zhou, Y.; Agarwal, A.; Lim, M.; Xu, Y.; Zhu, Y.; O’Brien, J.; Tran, E.; Zheng, J.; Gius, D.; et al. Systemic application of honokiol prevents cisplatin ototoxicity without compromising its antitumor effect. Am. J. Cancer Res. 2020, 10, 4416-4434. 
102. Fernandez, K.A.; Allen, P.; Campbell, M.; Page, B.; Townes, T.; Li, C.M.; Cheng, H.; Garrett, J.; Mulquin, M.; Clements, A.; et al. Atorvastatin is associated with reduced cisplatin-induced hearing loss. J. Clin. Investig. 2021, 131, e142616. [CrossRef]

103. Orgel, E.; Freyer, D.R.; Ullrich, N.J.; Hardy, K.K.; Thomas, S.M.; Dvorak, C.C.; Esbenshade, A.J. Assessment of provider perspectives on otoprotection research for children and adolescents: A Children's Oncology Group Cancer Control and Supportive Care Committee survey. Pediatr. Blood Cancer 2020, 67, e28647. [CrossRef] [PubMed]

104. Freyer, D.R.; Brock, P.R.; Chang, K.W.; Dupuis, L.L.; Epelman, S.; Knight, K.; Mills, D.; Phillips, R.; Potter, E.; Risby, D.; et al. Prevention of cisplatin-induced ototoxicity in children and adolescents with cancer: A clinical practice guideline. Lancet Child Adolesc. Health 2020, 4, 141-150. [CrossRef]

105. Waissbluth, S. Clinical trials evaluating transtympanic otoprotectants for cisplatin-induced ototoxicity: What do we know so far? Eur. Arch. Otorhinolaryngol. 2020, 277, 2413-2422. [CrossRef] [PubMed]

106. Viglietta, V.; Shi, F.; Hu, Q.Y.; Ren, Y.; Keilty, J.; Wolff, H.; McCarthy, R.; Kropp, J.; Weber, P.; Soglia, J. Phase 1 study to evaluate safety, tolerability and pharmacokinetics of a novel intra-tympanic administered thiosulfate to prevent cisplatin-induced hearing loss in cancer patients. Investig. New Drugs 2020, 38, 1463-1471. [CrossRef]

107. Duinkerken, C.W.; de Weger, V.A.; Dreschler, W.A.; van der Molen, L.; Pluim, D.; Rosing, H.; Nuijen, B.; Hauptmann, M.; Beijnen, J.H.; Balm, A.J.M.; et al. Transtympanic Sodium Thiosulfate for Prevention of Cisplatin-Induced Ototoxicity: A Randomized Clinical Trial. Otol. Neurotol. 2021, 42, 678-685. [CrossRef] [PubMed]

108. Kim, S.; Lee, S.; Cho, J.Y.; Yoon, S.H.; Jang, I.J.; Yu, K.S. Pharmacokinetics and tolerability of MB12066, a beta-lapachone derivative targeting $\mathrm{NAD}(\mathrm{P}) \mathrm{H}$ : Quinone oxidoreductase 1: Two independent, double-blind, placebo-controlled, combined single and multiple ascending dose first-in-human clinical trials. Drug Des. Dev. Ther. 2017, 11, 3187-3195. [CrossRef]

109. Breglio, A.M.; May, L.A.; Barzik, M.; Welsh, N.C.; Francis, S.P.; Costain, T.Q.; Wang, L.; Anderson, D.E.; Petralia, R.S.; Wang, Y.X.; et al. Exosomes mediate sensory hair cell protection in the inner ear. J. Clin. Investig. 2020, 130, $2657-2672$. [CrossRef]

110. Park, D.J.; Park, J.E.; Lee, S.H.; Eliceiri, B.P.; Choi, J.S.; Seo, Y.J. Protective effect of MSC-derived exosomes against cisplatin-induced apoptosis via heat shock protein 70 in auditory explant model. Nanomedicine 2021, 38, 102447. [CrossRef]

111. Rybak, L.P.; Whitworth, C.; Somani, S. Application of antioxidants and other agents to prevent cisplatin ototoxicity. Laryngoscope 1999, 109, 1740-1744. [CrossRef]

112. Kaur, T.; Mukherjea, D.; Sheehan, K.; Jajoo, S.; Rybak, L.P.; Ramkumar, V. Short interfering RNA against STAT1 attenuates cisplatin-induced ototoxicity in the rat by suppressing inflammation. Cell Death Dis. 2011, 2, e180. [CrossRef] 